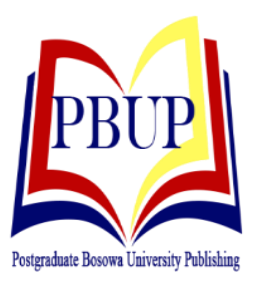

Postgraduate Bosowa University Publishing (PBUP)

Indonesian Journal of Business and Management e-ISSN: 2460-3767 p-ISSN: 2656-6885

https://postgraduate.universitasbosowa.ac.id/index.php/jbm

\title{
PENGARUH MOTIVASI DAN BUDAYA ORGANISASI TERHADAP KINERJA APARATUR SIPIL NEGARA DI POLDA SULAWESI SELATAN
}

\author{
The Effect of Motivation and Organizational Culture toward the Performance of Civil Servants \\ in South Sulawesi Regional Police
}

\author{
Darwis $^{1}$, Herminawati AB ${ }^{2}$, Thamrin Abduh ${ }^{2}$ \\ ${ }^{1}$ Kepolisian Daerah Sulawesi Selatan \\ ${ }^{2}$ Program Studi Manajemen Program Pascasarjana Universitas Bosowa \\ Email: crash_awhy29@yahoo.co.id
}

Diterima: 22 Juli 2020/Disetujui: 05 Desember 2020

\begin{abstract}
ABSTRAK
Tujuan penelitian ini untuk mengetahui pengaruh motivasi dan budaya organisasi terhadap kinerja Aparatur Sipil Negara di Polda Sulsel. Penelitian ini adalah penelitian kuantitatif dengan metode analisis regresi linear berganda. Sampel diambil dengan teknik "cluster sampling" sebanyak enam puluh satu orang dari populasi sebanyak seratus lima puluh tiga orang. Dari hasil analisis membuktikan bahwa ada pengaruh signifikan antara motivasi terhadap kinerja artinya kebutuhan akan pencapaian prestasi (need of achievement), kebutuhan akan kekuasaan (need of power, nPow), dan kebutuhan akan afiliasi (need of affiliation, nAff) mempengaruhi kinerja dari ASN di Polda Sulsel, demikian pula budaya organisasi berpengaruh signifikan terhadap kinerja artinya ASN di Polda Sulsel sudah menanamkan nilai-nilai Panca Prasetya Korps Pegawai Republik Indonesia dan Tribrata sebagai pedoman dan falsafah hidup dalam setiap pelaksanaan tugas.
\end{abstract}

Kata Kunci: Motivasi, Budaya Organisasi, Kinerja

\begin{abstract}
The research objective was to test the effect of motivation and organizational culture on the performance of the State Civil Servants at the South Sulawesi Regional Police. This study uses a quantitative approach with multiple regression analysis methods. The samples taken by "cluster sampling” technique were sixty one people from a population of one hundred and fifty three people. The analysis proves that there is a significant effect of motivation on performance, which means that the need for achievement, the need for power and the need for affiliation affect the performance of the State Civil Servants at the South Sulawesi Regional Police, and organizational culture has a significant effect on performance as well, meaning that civil servants in the South Sulawesi Regional Police already implement Panca Prasetya Korpri and Tribrata as a guide and philosophy of life in every task implementation.
\end{abstract}

Keywords: Motivation, Organizatonal Culture, Work Performance

\section{PENDAHULUAN}

Sebuah perusahaan atau organisasi dapat berjalan dan beroperasi dengan baik karena terdapat aktivitas setiap individu di dalamnya. Organisasi dapat hidup dan bertahan karena ada kegiatan manusia di dalamnya yang terstruktur dengan baik. Untuk menghasilkan kinerja pegawai yang optimal adalah tidak mudah karena kinerja dapat tercipta jika variabel-variabel yang mempengaruhinya seperti motivasi kerja dan budaya organisasi dapat diakomodasikan dengan baik dan diterima oleh semua pegawai di dalam suatu organisasi/perusahaan. Selain itu, kinerja juga dipengaruhi oleh sikap optimisme. Individu yang optimis cenderung memiliki kondisi mood yang stabil, tekun, berprestasi, dan kesehatan fisik yang baik (Alim \& Rakhmat, 2020). Selanjutnya, jika ditinjau dari aspek budaya organisasi, seringkali terjadi perbedaan persepsi antara ASN (Aparatur Sipil Negara) polri dalam melihat dan memaknai budaya organisasi tersebut. Sumber Daya Manusia (pegawai) merupakan unsur yang strategis dalam menentukan sehat tidaknya suatu 
organisasi. Pengembangan SDM yang terencana dan berkelanjutan merupakan kebutuhan yang mutlak terutama untuk masa depan organisasi (Edowai, 2020).

Kondisi tersebut berdampak pada belum tingginya kualitas capaian kinerja. Lingkungan kerja dan hubungan antara ASN polri nampaknya belum terlalu kondusif sehingga pengelolaan tugas-tugas pelayanan belum efektif. Untuk variabel motivasi, sebagian ASN belum memiliki motivasi kerja dan komitmen organisasi yang tinggi untuk mencapai keberhasilan. Beberapa ASN merasa nyaman dengan jabatan sekarang dan kesibukan yang luar biasa menyebabkan mereka tidak memiliki kesempatan untuk mengembangkan diri. Selain itu, motivasi mereka khususnya dalam menyelesaikan tugas dan tanggung jawab sebagai aparatur sipil negara, ASN tidak terlalu mengindahkan nilai-nilai kebersamaan dan belum sepenuhnya dilaksanakan secara konsisten. Melihat kesenjangan tersebut, penelitian ini bermaksud untuk mengetahui pengaruh motivasi dan budaya organisasi terhadap kinerja Aparatur Sipil Negara di Polda Sulawesi Selatan.

\section{METODE PENELITIAN}

Penelitian ini dilakukan pada Kantor Polda Sulawesi Selatan yang berlokasi di Jalan Perintis Kemerdekaan Km. 16 Makassar. Sedangkan waktu yang diperlukan untuk penelitian adalah 2 (dua) bulan, yaitu dari bulan Juli sampai dengan bulan Agustus 2020. Populasi dalam penelitian ini sebanyak 153 orang yang berstatus Pegawai Negeri Sipil di Polda Sulsel. Teknik pengambilan sampel menggunakan proportional random sampling. Berdasarkan perhitungan maka diketahui jumlah sampel ASN yang akan digunakan pada penelitian ini adalah sebanyak 61 orang.

Teknik pengumpulan data yang dilakukan dalam penelitian ini adalah dengan metode kuesioner. Metode ini menggunakan sejumlah pertanyaan tertulis yang digunakan untuk memperoleh informasi dari responden (Arikunto, 2002). Pertanyaan-pertanyaan dalam daftar pertanyaan dibuat dengan menggunakan skala likert dengan menggunakan lima variabel pilihan, setiap tingkatan diberi skor mulai dari tingkat yang rendah dengan skor 1 hingga tingkatan yang paling tinggi dengan skor 5. Sebelum kuisioner digunakan dalam pengumpulan data terlebih dahulu diuji validitas dan reabilitasnya. Teknik yang digunakan untuk menguji model dan hipotesis yang digunakan adalah analisis regresi linear berganda, uji parsial, uji signifikan simultan, dan uji koefisien determinasi.

\section{HASIL DAN PEMBAHASAN}

Hasil uji instrumen kuesioner motivasi $\left(\mathrm{X}_{1}\right)$ dan budaya organisasi $\left(\mathrm{X}_{2}\right)$ serta kinerja $(\mathrm{Y})$ ditunjukkan pada Tabel 1. berikut:
Tabel 1. Hasil Uji Validitas Kuesioner

\begin{tabular}{cccc}
\hline $\begin{array}{c}\text { Item } \\
\text { (Indikator) }\end{array}$ & r Hitung & r Tabel & Status \\
\hline X1.1 & 0,802 & 0,2521 & valid \\
X1.2 & 0,668 & 0,2521 & valid \\
X1.3 & 0,817 & 0,2521 & valid \\
X2.1 & 0,568 & 0,2521 & Valid \\
X2.2 & 0,669 & 0,2521 & Valid \\
X2.3 & 0,623 & 0,2521 & Valid \\
X2.4 & 0,486 & 0,2521 & Valid \\
X2.5 & 0,641 & 0,2521 & Valid \\
X2.6 & 0,578 & 0,2521 & Valid \\
Y.1 & 0,768 & 0,2521 & Valid \\
Y.2 & 0,746 & 0,2521 & Valid \\
Y.3 & 0,788 & 0,2521 & Valid \\
\hline
\end{tabular}

Sumber: Data Primer, Diolah 2020

Hasil uji validitas menunjukkan setiap kuisioner telah menunjukkan validitas. Nilai $\mathrm{r}$ hitung $>0.2521$ ( $\mathrm{r}$ tabel), sehingga menunjukkan bahwa semua butir pernyataan pada kuisioner motivasi $\left(\mathrm{X}_{1}\right)$ dan budaya organisasi $\left(\mathrm{X}_{2}\right)$ serta kinerja (Y) adalah valid atau mampu mengungkapkan sesuatu yang akan diukur oleh kuisioner tersebut.

Tabel 2. Hasil Uji Reliabilitas Instrumen Penelitian

\begin{tabular}{lccc}
\hline \multicolumn{1}{c}{ Variabel } & $\begin{array}{c}\text { Cronbach's } \\
\text { Alpha }\end{array}$ & $\begin{array}{c}\text { Cut of } \\
\text { Point }\end{array}$ & Status \\
\hline Motivasi $\left(\mathrm{X}_{1}\right)$ & 0,641 & 0.60 & Reliabel \\
\hline $\begin{array}{l}\text { Budaya organisai } \\
\left(\mathrm{X}_{2}\right)\end{array}$ & 0,617 & 0.60 & Reliabel \\
\hline Kinerja ASN (Y) & 0,651 & 0.60 & Reliabel \\
\hline
\end{tabular}

Sumber: Data Primer, Diolah 2020

Hasil pengujian reliabilitas dengan metode Cronbach's Alpha dapat diketahui bahwa nilai koefisien reliabilitas yang diukur adalah $\geq 0.60$. Masing-masing variabel berada diatas ambang batas (cut of point) 0.60 , maka dapat disimpulkan bahwa seluruh variabel memiliki tingkat keandalan yang dapat diterima.

Uji asumsi klasik digunakan sebagai syarat dalam menggunakan model regresi agar hasil regresi yang diperoleh merupakan estimasi yang tepat. Adapun hasil uji asumsi klasik tersebut meliputi:

\section{a. Uji Normalitas}

Tabel 3. Hasil Uji Normalitas Data dengan KolmogorovSmirnov

\begin{tabular}{ccccc}
\hline Variabel & $\begin{array}{c}\text { Kolmogor } \\
\text { Smirnov }\end{array}$ & $\begin{array}{c}\text { Asymp.s } \\
\text { ig }\end{array}$ & Sig & Status \\
\hline Motivasi & 1.312 & 0.064 & $>0,05$ & Normal \\
\hline $\begin{array}{c}\text { Budaya } \\
\text { Organisasi }\end{array}$ & 0.742 & 0.641 & $>0,05$ & Normal \\
\multicolumn{2}{l}{ Sumber: Data Primer, Diolah 2020} & & &
\end{tabular}

Dari hasil perhitungan uji Kolmogorov-Smirnov, maka dapat diketahui bahwa apabila Signifikansi (Asymp.sig) > 0,05 maka data berdistribusi normal, dan sebaliknya apabila Signifikansi (Asymp.sig) $<0,05$ maka data tidak berdistribusi normal. Pada output data table di atas dapat diketahui bahwa variabel motivasi (X1) nilai 
Asymp.sig (2-tailed) sebesar 0,064, dan variabel budaya organisasi (X2) sebesar 0,64. Dengan demikian karena Signifikansi pada kedua variabel lebih dari 0,05 maka dapat dinyatakan data berdistribusi normal.

b. Uji Multikolieritas

Hasil perhitungan multikolonieritas antar masingmaing variabel bebas sebeagai berikut:

Tabel 4. Hasil Perhitungan VIF

\begin{tabular}{lcc}
\hline \multirow{2}{*}{ Model } & \multicolumn{2}{c}{ Collinearity Statistics } \\
& Tolerance & VIF \\
\hline Motivasi (x1) &, 896 & 1,116 \\
Budaya kerja (x2) &, 896 & 1,116 \\
\hline
\end{tabular}

Sumber: Data Primer, Diolah 2020

Dalam mendeteksi ada tidaknya gejala multikolinearitas antar variabel independen pada model persamaan maka digunakan variance inflation factor (VIF). Berdasarkan hasil yang ditunjukkan dalam output SPSS maka besarnya VIF dari masing-masing variabel independen motivasi: 0.896; dan budaya kerja: 0,896 lebih besar dari nilai batas yang ditentukan yaitu sebesar 0,01 . Untuk nilai VIF terlihat bahwa semua variabel bebas memiliki nilai VIF yang kurang dari 10 (motivasi: 1.116; dan budaya kerja: 1.116). Maka dapat disimpulkan tidak terdapat gejala multikolinieritas antar variabel bebas dalam penelitian ini.

c. Uji Autokorelasi

Hasil perhitungan uji autokorelasi dapat dilihat pada tabel di bawah ini:

Tabel 5. Uji Autokorelasi

\begin{tabular}{cc|c|r|r|r}
\hline Model & $\mathrm{R}$ & $\begin{array}{c}\mathrm{R} \\
\text { Square }\end{array}$ & $\begin{array}{c}\text { Adjusted R } \\
\text { Square }\end{array}$ & $\begin{array}{l}\text { Std. Error of } \\
\text { the Estimate }\end{array}$ & $\begin{array}{l}\text { Durbin- } \\
\text { Watson }\end{array}$ \\
\hline 1 &, $821^{\mathrm{a}}$ &, 675 &, 664 &, 34487 & 1,912 \\
\hline Sumber: Data Primer, Diolah 2020 &
\end{tabular}

Berdasarkan hasil output uji autokorelasi, diperoleh hasil output Durbin Watson sebesar 1,912. Berdasarkan aturan statistic autokorelasi, data dikatakan bebas dari autokorelasi bila memenuhi rumus: $\mathrm{Du}<\mathrm{Dw}<4-\mathrm{Du}$. Diperoleh nilai Du pada tabel Durbin Watson dengan sig. 0,05 sebesar 1,484 . Maka rumus dapat ditulis sebagai berikut: $1,484<1,912<2,516$ sehingga disimpulkan data bebas dari autokorelasi.

Selanjutnya pengujian hipotesis dilakukan dengan menggunakan analisis regresi linier berganda, Uji Parsial Dengan T-Test, Uji Simultan Dengan F-Test (Anova ${ }^{\mathrm{b}}$ ) dan Uji Koefisien Determinasi (R Square), setelah data ordinal diubah ke data interval.

Untuk melihat pengaruh motivasi, dan budaya organisasi terhadap kinerja ASN Polri, maka digunakan analisa regresi linear berganda. Berdasarkan hasil pengolahan data dengan bantuan program SPSS dapat dilihat rangkuman hasil empiris penelitian sebagai berikut:

Tabel 6. Output Hasil Regresi Berganda

\begin{tabular}{lccc}
\hline \multicolumn{1}{c}{ Variabel } & $\begin{array}{c}\text { Koefisien } \\
\text { Regresi }\end{array}$ & $\begin{array}{c}\text { T } \\
\text { hitung }\end{array}$ & Sig \\
\hline Konstanta & -.238 & -.478 & .628 \\
Motivasi (X1) & .243 & 3.174 & .002 \\
Budaya Organisasi & .839 & 8.918 & .000 \\
(X2) & & & \\
R2 & .675 & & \\
F Hitung & 60.168 & & \\
Sig (f) & .000 & &
\end{tabular}

Persamaan regresi berganda yang diperoleh dari hasil analisis yaitu $\mathrm{Y}=-238+0,243 \mathrm{X} 1+0,839 \mathrm{X} 2$ yang maknanya:

1. Konstantanta $-0,238$, nilai konstanta bernilai negatif artinya jika skor variabel motivasi dan budaya organisasi dianggap tidak ada atau sama dengan nol, maka skor kinerja ASN di Polda Sulsel akan semakin berkurang.

2. Koefisien X1 0,243, koefisien variabel motivasi bernilai positif artinya pengaruh motivasi terhadap kinerja ASN di Polda Sulsel adalah bernilai positif dan cukup kuat. Jika motivasi membaik maka kinerja juga meningkat.

3. Koefisien X2 0,839, koefisien variabel budaya organisasi bernilai positif artinya pengaruh budaya organisasi terhadap kinerja ASN di Polda Sulsel adalah bernilai positif dan cukup kuat. Jika budaya organisasi membaik maka kinerja semakin tinggi.

Berdasarkan data di atas, diperoleh nilai $\mathrm{R}$ square sebesar 0,675 artinya untuk uji Koefisien Determinasi, terdapat $67,5 \%$ pengaruh faktor Motivasi Kerja dan Budaya organisasi Terhadap Kinerja ASN Polri, dan 32,5\% lainnya dipengaruhi oleh faktor lain.

Selanjutnya uji simultan dengan F-Test (Anova ${ }^{\mathrm{b}}$ ) bertujuan untuk menentukan apakah secara serentak/bersama-sama variabel independen mampu menjelaskan variabel dependen dengan baik atau apakah variabel independen secara bersama-sama mempunyai pengaruh yang signifikan terhadap variabel dependen. Berdasarkan hasil output di atas menunjukkan bahwa hasil pengujian hipotesis dengan perhitungan uji $\mathrm{F}$ menggunakan program SPSS for Windows diperoleh $\mathrm{F}$ hitung $=60,168$ yang lebih besar dari $\mathrm{F}$ tabel sebesar 2,76 dan dengan harga signifikansi sebesar 0.000. Karena harga signifikansi kurang dari 0.05 , menunjukkan bahwa nilai $\mathrm{F}$ hitung yang diperoleh tersebut signifikan.

Sementara itu hasil uji parsial dengan menggunakan T-Test dilakukan untuk mengetahui apakah semua variabel independen $(\mathrm{X})$ mempunyai pengaruh yang sama 
terhadap variabel dependen (Y). Berdasarkan hasil output di atas, diperoleh bahwa:

1. Nilai $\mathrm{t}$ hitung untuk variabel motivasi terhadap kinerja diperoleh 3.174 dengan harga signifikansi 0.002 menunjukkan bahwa nilai $\mathrm{t}$ yang diperoleh tersebut signifikan karena harga signifikansi yang diperoleh kurang dari 0.05 .

2. Nilai t hitung untuk variabel budaya organisasi terhadap kinerja diperoleh 8,918 dengan harga signifikansi 0.000 menunjukkan bahwa nilai t yang diperoleh tersebut signifikan karena harga signifikansi yang diperoleh kurang dari 0.05 .

Dari hasil uji t didapatkan hasil bahwa motivasi berpengaruh positif dan signifikan terhadap kinerja ASN Polri, hal ini terlihat pada hasil uji parsial/uji t dengan nilai signifikansinya adalah $0,002<0,05$. Nilai t hitung untuk motivasi terhadap kinerja ASN diperoleh 3.174 dengan harga signifikansi 0.002 menunjukkan bahwa nilai $\mathrm{t}$ yang diperoleh tersebut signifikan karena harga signifikansi yang diperoleh kurang dari 0.05 . Karena nilai t hitung 3.174 lebih besar dari t tabel 1.671 maka hipotesis nol (H0) ditolak dan hipotesis satu (H1) diterima, sehingga hal ini berarti bahwa variabel motivasi $\left(\mathrm{X}_{1}\right)$ memiliki pengaruh yang signifikan terhadap kinerja $\operatorname{ASN}(\mathrm{Y})$.

Hasil penelitian ini sejalan dengan pernyataan Mangkunegara (2011 : 68), bahwa ketiga kebutuhan yakni need of affiliation, need of achievement dan need of power disebut sebagai "virus mental" yang ada pada diri seseorang. Virus mental adalah kondisi jiwa yang mendorong seseorang mampu mencapai prestasinya secara maksimal. Hasil penelitian ini juga mendukung hasil penelitian sebelumnya dari H. Teman Koesmono (2005), kesimpulan yang diperoleh adalah secara langsung motivasi berpengaruh terhadap kepuasan kerja dan motivasi berpengaruh terhadap kinerja Karyawan Pada Sub Sektor Industri Pengolahan Kayu Skala Menengah Di Jawa Timur. Berdasarkan hasil ini sehingga hipotesis 1 yang menyatakan motivasi kerja berpengaruh terhadap kinerja ASN Polri di Polda Sulawesi Selatan, diterima.

Dari hasil uji t anova didapatkan hasil bahwa Budaya Organisasi memiliki pengaruh secara simultan terhadap Kinerja ASN Polri, hal ini terlihat dari nilai signifikansinya $0,000<0,05$. Nilai t hitung untuk variabel budaya organisasi terhadap kinerja ASN diperoleh 8.918 dengan harga signifikansi 0.000 menunjukkan bahwa nilai $\mathrm{t}$ yang diperoleh tersebut signifikan karena harga signifikansi yang diperoleh kurang dari 0.05. Karena nilai t hitung 8.918 lebih besar dari t tabel 1.671 maka hipotesis nol (H0) ditolak dan hipotesis dua (H2) diterima, sehingga hal ini berarti bahwa variabel budaya organisasi $\left(\mathrm{X}_{2}\right)$ memiliki pengaruh yang signifikan terhadap kinerja ASN (Y).

Hasil penelitian ini sejalan dengan pernyataan Yukl, 2010, bahwa nilai-nilai budaya dapat mempengaruhi sikap dan perilaku pegawai. Nilai budaya mempengaruhi perilaku pegawai baik yang berorientasi tugas (task oriented), berorientasi hubungan (relations oriented) maupun yang berorientasi perubahan (change oriented). Dengan demikian, budaya organisasi berkontribusi terhadap perilaku pegawai dalam melaksanakan tugas, membangun hubungan, dan melakukan perubahan untuk mencapai tujuan yang diharapkan (kinerja organisasi).

Hasil penelitian ini juga mendukung hasil penelitian sebelumnya dari Leo Addy Chandra (2013), Temuan hasil penelitian menunjukkan bahwa budaya organisasi mempunyai hubungan (korelasi) yang positif terhadap kinerja pegawai Kantor Ketahanan Pangan dan Penyuluhan Kabupaten Kutai Barat hal tersebut berarti bahwa semakin baik budaya organisasi maka semakin baik kinerja pegawai. Berdasarkan hasil ini sehingga hipotesis 2 yang menyatakan budaya organisasi berpengaruh terhadap kinerja ASN Polri di Polda Sulawesi Selatan, diterima.

Berdasarkan Tabel. 1 menunjukkan bahwa hasil pengujian hipotesis dengan perhitungan uji $F$ menggunakan program SPSS for Windows diperoleh $\mathrm{F}$ hitung $=60,168$ yang lebih besar dari $\mathrm{F}$ tabel sebesar 2,76 dan dengan harga signifikansi sebesar 0.000. Karena harga signifikansi kurang dari 0.05 , menunjukkan bahwa nilai F hitung yang diperoleh tersebut signifikan. Dengan demikian menunjukkan bahwa secara bersama-sama terdapat pengaruh yang signifikan motivasi dan budaya kerja terhadap kinerja ASN di Polda Sulsel. Sehingga dapat disimpulkan bahwa Motivasi Kerja dan Budaya Organisasi memiliki hubungan secara simultan terhadap Kinerja ASN Polri di Mapolda Sulsel. Hal ini berarti bahwa semakin tinggi motivasi dan semakin baik budaya organisasi maka kinerja ASN Polri akan semakin meningkat.

Berdasarkan hasil perhitungan diperoleh nilai $R$ square sebesar 0,675 artinya untuk uji Koefisien Determinasi, terdapat $67,5 \%$ pengaruh faktor Motivasi Kerja dan Budaya organisasi Terhadap Kinerja ASN Polri, dan 32,5\% lainnya dipengaruhi oleh faktor lain yang tidak dimasukkan ke dalam penelitian ini. Artinya bahwa, besarnya pengaruh motivasi dan budaya organisasi dilingkungan kerja ASN Polri Polda Sulawesi Selatan dalam mempengaruhi kinerja ASN Polri cukup kuat. 
Berdasarkan hasil penelitian terbukti bahwa budaya organisasi berpengaruh terhadap kinerja ASN Polri di Polda Sulsel. Hal ini sesuai dengan pernyataan Robbins (2002: 247- 248) menyatakan setelah nilai-nilai dan karakteristik budaya organisasi terinternalisasi, pengaruhnya akan tampak lebih signifikan antara lain kepada kepuasan kerja ataupun kinerja dari para anggota organisasi, dan menurut Sunyoto, (2015) motivasi penting karena dengan motivasi diharapkan setiap individu karyawan mau bekerja keras dan antusias untuk mencapai produktivitas kerja yang tinggi. Hasil penelitian ini mendukung hasil penelitian sebelumnya dari Eddy \& Zulfikar (2010), kesimpulan yang di dapat secara bersamaan budaya organisasi dan motivasi kerja berpengaruh positif dan signifikan terhadap kinerja Karyawan pada Dinas Perhubungan Kota Bandar Lampung. Berdasarkan hasil diatas maka hipotesis 3 yang menyatakan motivasi dan budaya organisasi secara bersama-sama berpengaruh terhadap kinerja ASN Polri di Polda Sulawesi Selatan, diterima.

\section{KESIMPULAN DAN SARAN}

Hasil penelitian dan pembahasan dapat disimpulkan bahwa motivasi berpengaruh terhadap kinerja ASN di Polda Sulsel. Motivasi terkhusus kebutuhan akan pencapaian prestasi (need of acheivement), kebutuhan akan kekuasaan (need of power), dan kebutuhan akan afiliasi (need of affiliation) mempengaruhi kinerja dari ASN di Polda Sulsel. Hal ini berarti semakin tinggi motivasi maka kinerja ASN di Polda Sulsel makin meningkat. Budaya organisasi adalah suatu pola asumsi dasar yang berkenaan dengan kepercayaan nilai-nilai, dan tingkah laku yang diciptakan dan dikembangkan oleh suatu organisasi sebagai dasar dalam menentukan tujuan, konsensus, keunggulan, prestasi (kinerja), inovasi, kesatuan, keakraban, dan intergritas organisasi. Dimensi budaya organisasi mempengaruhi kinerja ASN di Polda Sulsel.

Berdasarkan kesimpulan di atas maka saran yang diberikan yaitu untuk penelitian yang akan datang disarankan untuk menambahkan variabel independen lainnya selain motivasi kerja dan budaya organisasi yang tentunya dapat mempengaruhi variabel dependen kinerja ASN Polri agar lebih melengkapi penelitian ini karena masih ada variabel-variabel independen lain diluar penelitian ini yang mungkin bisa mempengaruhi kinerja ASN Polri di Polda Sulsel.

\section{DAFTAR PUSTAKA}

Alim, S., \& Rakhmat, H. A. B. (2020). The Construction of Academic Optimism Scale (AOS) to Describe Optimism in Educational Setting. Ecosystem, 20, 199-206.

Arikunto, S. 2002. Prosedur Penelitian, Suatu Pendekatan Praktek Edisi Revisi V. Jakarta: Rineka Cipta.

Chandra, Leo Addy. (2013) Pengaruh Budaya Organisasi Terhadap Kinerja Pegawai Kantor Ketahanan
Pangan dan Penyuluhan Kabupaten Kutai Barat. eJournal Administrasi Negara, 1 (3), 885-889.

Eddy, Kisro dan Zulfikar, Iwan. (2010). Pengaruh Budaya organisasi dan Motivasi Kerja terhadap Kinerja Karyawan pada Dinas Perhubungan kota Bandar Lampung. Jurnal Sains dan Inovasi. (6)1.91-97. Retrieved from Jurnal Sains dan Inovasi Universitas Bandar Lampung

Edowai, R., Abubakar, H., \& Mane, A. (2021). Pengaruh Kepemimpinan, Budaya Organisasi Dan Disiplin Kerja Terhadap Kinerja Pegawai Pada Dinas Kesejahteraan Sosial Kabupaten Deiyai Provinsi Papua. Indonesian Journal of Business and Management, 2(2), 121-127. https://doi.org/10.35965/jbm.v2i2.473

Koesmono, H. Teman (2005) Pengaruh Budaya Organisasi Terhadap Motivasi dan Kepuasan Kerja serta Kinerja Karyawan Pada Sub Sektor Industri Pengolahan Kayu Skala Menengah Di Jawa Timur. Jurnal Manajemen \& Kewirausahaan, Vol. 7, No. 2, September 2005: 171-188.

Mangkunegara, Anwar Prabu. 2007. Evaluasi Kinerja SDM. Bandung : PT. Refika Aditama

Robbins, Stephen P. 2002. Prinsip-prinsip Perilaku Organisasi. Terjemahan Halida, Dewi Sartika. Erlangga. Jakarta.

Yukl, Gary. 2010. Leadership in Organizations (7th edition). Jakarta: PT. Indeks. 